\title{
Article
}

\section{Additional Effect of SEBS on Dynamic Mechanical Properties in iPP/aPS Blends}

\author{
Kazuhiro YoshIDA*, Takanobu KAWAMURA ${ }^{* *}$, Minoru TERANO ${ }^{* * *}$, and Koh-hei NITTA ${ }^{* * \dagger}$ \\ ${ }^{*}$ Tokyo Printing Ink Mfg, Yoshinohara, Kitaku, Saitama, 331-0811 Japan \\ ${ }^{* *}$ Graduate School of Natural Science and Technology, Kanazawa University, \\ Kakuma, Kanazawa, Ishikawa, 920-1192 Japan \\ ${ }^{* * *}$ School of Materials Science, Japan Advanced Institute of Science and Technology, \\ Nomi, Ishikawa, 923-1292, Japan
}

\begin{abstract}
Dynamic mechanical properties of binary and ternary blends of isotactic polypropylene (PP), atactic polystyrene (PS) and poly(styrene-b-ethylene-co-butylene-b-styrene (SEBS)) were investigated. The glass transition temperature of PS domains in PP/PS and PP/PS/SEBS composites becomes higher with PP content owing to the low activation entropy of the glass transition of PS domains. The PS domain size and the relaxation strength of the PS glass transition decrease by the increase of SEBS for PP/PS/SEBS composites with less than $2.5 \mathrm{phr}$ SEBS content, while the domain size and the relaxation strength become constant for the composites with over 2.5 phr SEBS content.
\end{abstract}

Key Words: Isotactic polypropylene / Atactic polystyrene / SEBS / Glass transition temperature

\section{PP/PS 系の動的粘弾性特性に及ぼす SEBS の添加効果}

\author{
吉田 和宏 ${ }^{*}$, 河村 幸伸 ${ }^{* *}$, 寺野 稔 ${ }^{* * *}$, 新田 晃平 ${ }^{* * \dagger}$ \\ （原稿受理：2007年6月 8日）
}

1. 緒言

今日に至るまで, 即在の複数の高分子材料を混ぜ合わせるこ とで新規高分子材料への応用を目的としたポリマーブレンド の研究が数多く報告されている. ポリマーブレンドの研究にお いて, 大半の異種ポリマーは非相溶であるためにさまざまな相 容化剂をブレンド系に添加し検討が行われてきた.このような 相容化剂の中で, SEBS( poly(styrene-b-ethylene-co-butylene-bstyrene ))やマレイン酸変性を施したSEBS(SEBS-g-MA)はさま ざまな組み合わせのポリマーブレンドの相容化剤として機 能することが知られている. 結晶性-結晶性と結晶性-非晶性 のポリマーブレンドの組み合わせとして, LDPE/PA6 $6^{1,2)}$, PA6/ $\mathrm{PP}^{3-7)}, \mathrm{HDPE} / \mathrm{s}-\mathrm{PS}^{8)}$ と PS/LDPE ${ }^{9,10)}, \mathrm{PA} 6 / \mathrm{PC}^{11)}$ などが適量のSEBS あるいはSEBS-g-MAを添加することで界面張力が低下し, 分 散状態が改善したと報告されている.さらに, PA6/PP系では ドメインであるPPの周りをSEBS-g-MAが覆いPA6とPP間の界 面がSEBS-g-MAを介して癒着力が向上することで降伏応力 が上昇したと報告されている.3)

\footnotetext{
$\dagger$ To whom correspondence should be addressed.

E-mail: nitta@t.kanazawa-u.ac.jp, Tel: +81-76-264-4818,FAX: +81-76-264-6221,

Graduate School of Natural Science and Technology, Kanazawa University, Kakuma,

Kanazawa, Ishikawa, 920-1192 Japan

* 東京インキ株式会社 † 331-0811 埼玉県さいたま市北区吉野町

** 金沢大学大学院 自然科学研究科 T 920-1192 石川県金沢市角間町

*** 北陸先端科学技術大学院大学マテリアルサイエンス † 923-1292 石川県能美市
}

このようなポリマーブレンドの中でイソタクチックポリ プロピレン(i-PP)とアタクチックポリスチレン(a-PS)の組み合 わせは興味深い。これらのポリマーは我々の日常に必要不可 欠な高分子材料となっており，大量に生産された後に両者の 材料が混ざり合って廃棄される場合が多い。したがって，ブ レンド物の力学的特性を詳細に調べることは，新規材料への 応用のみならず, PP とPSのリサイクルを考える上で重要であ ると言える. PP/PS系も他のポリマーブレンドと同様に非相 溶であり, SEBSのような相容化剂を添加し分散性および力学

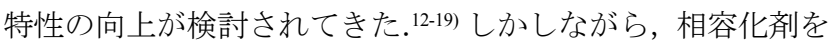
添加した系では相容化剂そのものがPPおよびPS 単体の力学 的性質に影響を及ぼすとも考えられ，単純にPP/PS系の力学 的性質を決定するパラメータが分散状態のみとは考えるこ とが出来ない，それゆえ，相容化剂の正確な添加効果を明ら かにするためには, 二成分 PP/PS系の力学的性質の詳細な知 見が必要となる。

以前，我々はPP-rich PP/PS系の延伸特性が分散相であるPS のサイズではなくマトリックスポリマーであるPPの力学特 性に支配的な影響を受けることを明らかとした. ${ }^{20)} \mathrm{PP}$ と PSの 界面の癒着力が低いために, 弾性率が低いPP相が優先的に変 形し，分散相であるPSに力が伝播せず，分散状態がブレンド 物の力学特性に反映されなかったと考えられる. それゆえ, PP/PS系の延伸特性に及ぼすSEBSの添加効果は界面の癒着力 の改善であるといえる.また, Muchaは二成分のPP-rich PP/PS 
系ブレンドにおいてPSのガラス転移温度が高温側へシフト すると報告しているが詳細な原因は分かっていない.21)

近年の，PP/PS/相容化剂系の研究はモルホロジ一制御と力 学的特性の向上を分けて考察するようになったとはいえ，動 的粘弾性特性に関する報告はわずかである。そこで，本研究 ではPSのガラス転移付近に着目し，二成分PP/PS系のモルホ ロジーが動的粘弾性特性およびPSのガラス転移温度に与え る影響を明らかにした上で，SEBSがPP/PS系の動的粘弾性特 性やPSのガラス転移温度に及ぼす影響についての調査を目 的とした。

\section{2. 実 験}

\section{1 試料調製}

本研究では, 日本ポリプロ社より提供されたイソタクチッ クポリプロピレン $\left(M_{\mathrm{n}}=8.0 \times 10^{4}, M_{\mathrm{w}} / M_{\mathrm{n}}=4.7\right)$ とアタクチックポ リスチレン $\left(M_{\mathrm{n}}=9.0 \times 10^{4}, M_{\mathrm{w}} / M_{\mathrm{n}}=2.4\right)$ を試料として用いた。 た，相容化剤である $\operatorname{SEBS}\left(M_{\mathrm{n}}=5.1 \times 10^{4}, M_{\mathrm{w}} / M_{\mathrm{n}}=1.2\right.$,PS含有量 : $53 \mathrm{wt} \%)$ はJSR社製を用いた。

各混合物は高速回転ミキサー（東京インキ社製）を用い, 仕込み量 $40 \mathrm{~g}$, 回転数 $5100 \mathrm{rpm}$ で混練することで得た。混練 後, $503 \mathrm{~K}$ で加熱し, 圧力 $10 \mathrm{MPa}$ で5分間プレスした後, $273 \mathrm{~K}$ のウォーターバスに投入することにより厚さ $200 \mu \mathrm{m}$ のサン プルシートを調製した。

\section{3. 測 定}

\section{1 モルホロジー}

サンプルシートを液体窒素中で脆性的に破断させた破断 面を金で蒸着した後, SEM(HITACHI-4500)によりブレンド物 のモルホロジーの観察を行った。 また，分散相サイズの観察 時はPSおよびSEBSが溶解するキシレンを用いてエッチング 処理を行った後にSEM観察を行った。

\section{2 動的粘弾性特性}

動的粘弾性特性は動的粘弾性測定機 (Rheology.Co.,Ltd.DVE V-4)を用いて厚さ $200 \mu \mathrm{m}$, 幅 $3 \mathrm{~mm}$, 長さ $30 \mathrm{~mm}$ の短冊形の サンプル片に, 0.1-100 Hz で引張振動を加え, 測定温度 193 448 K, 昇温速度 $2 \mathrm{~K} / \mathrm{min}$ でひずみ振動に対する応力の 応答を測定した。

\section{3 結果と考察}

Fig. 1 に, 二成分PP/PS系 $(10 / 90,50 / 50,90 / 10)$ およ゙相容化剤 であるSEBSを各混合比のサンプルに $5 \mathrm{phr}$ 添加したPP/PS/ SEBS系のSEM写真を示す.PP/PS系ブレンドでは典型的な海 島構造を示し，10/90系はPPがドメイン，90/10系はPSがドメ インを形成している. 近年の我々の研究で, PS含有量が $67.5 \mathrm{wt} \%$ 前後でPP とPSの分散相と連続相の転移が生じること を明らかとしており ${ }^{200}$ 50/50系はPSがドメイン, PPがマトリッ クスを形成していることになる。一方，PP/PS/SEBS系では SEBSの添加により劇的に分散相のサイズが低減するものの, PP/PS(50/50)系にSEBSを5 phr添加した系では分散相が凝集体 を形成していることが分かった. Hobbsら 22)による界面張力を 基にした現象論モデルに従えば, PP/PS/SEBS系ブレンドのモ ルホロジーは，PPとPS，PSとSEBS，PPとSEBSの各二成分間
の界面張力と PP/PS/SEBS系の自由エネルギーから推測する ことが出来る。彼らは，PP とPS間の相容性がPP と SEBSある いはPS とSEBSの相容性よりも低い場合, SEBSはPSドメイン を覆い囲む形状の一次分散体を形成しPPマトリックスに分 散するとしている．実際にこのような一次分散体が形成され ると, SEBS同士の癒着により一次分散体が凝集し，二次分散 体が形成されると考えられる。それゆえ，SEM写真で観察さ れた分散相の凝集体は一次分散体であるSEBSに取り囲まれ たPSドメイン（直径 $50 \mathrm{~nm}$ 程度）がSEBSを介して繫がった二 次分散体であると予想される。また, SEPS(poly(styrene-bethylene-co-propylene--b-styrene)) をPP-rich PP/PS 系ブレンドに 添加した場合においても同様の分散状態をRheeら ${ }^{15)}$ が報告し ている。

Fig. 2 に二成分PP/PS系と SEBSを 5 phr添加した三成分PP/PS/ SEBS系の平均分散相直径の比較結果を示寸. 平均分散相サイ ズは，キシレンにより室温でエッチング処理を施した試料の SEM写真より読み取って決定した。キシレンへはPSとSEBS のみが溶解するため，PP/PS系ではPSドメイン，PP/PS/SEBS 系ではSEBSに覆われたPSドメインである一次分散体もしく は一次分散体の凝集体である二次分散体のみを溶出させるこ とができる。これら分散相の直径を測定して分散相サイズと した．PP/PS系，PP/PS/SEBS系ともに分散相サイズはPS含有 量の増加に伴い直線的に増加するが, SEBSを 5 phr添加するこ とで分散相サイズおよびそのサイズ分布は劇的に低下した. これはSEBSがPP とPS間の界面を安定化させPSドメインの成 長が抑制され, なおかつ二次分散体サイズが元のPP/PS系のPS ドメインサイズほど成長しなかったためと考えられる。

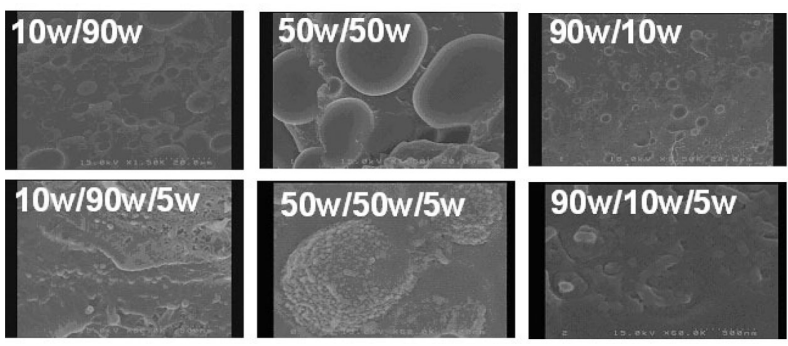

Fig. 1. SEM micrographs of PP/PS and PP/PS/SEBS blends.

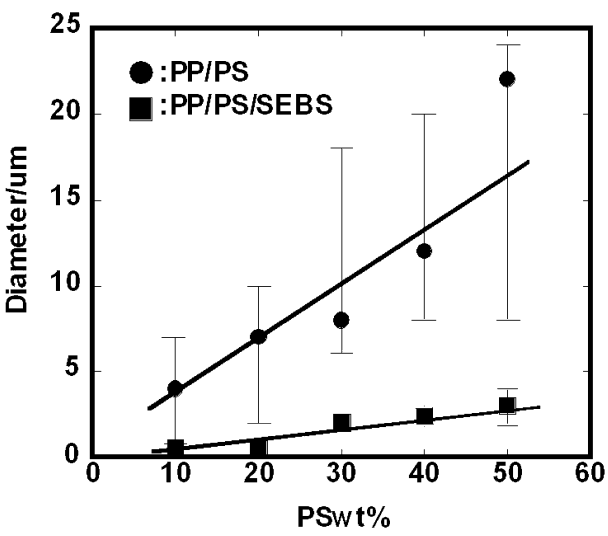

Fig. 2. Plot of diameter of PS domains with different content of PS for $\mathrm{PP} / \mathrm{PS}$ and PP/PS with SEBS(5 wt $\%$ ). 
次に, SEBSの添加量がPP-rich PP/PS系の分散相サイズに与 える影響について調査を行った. Fig. 3 にSEBSの添加量に伴 う PP/PS系の分散相サイズの変化を示す. PP/PS系にSEBSを $2.5 \mathrm{phr}$ 添加することでPS含有量に関係なくPS分散相サイズは 劇的に低下寸るものの, SEBSの添加量が $2.5 \mathrm{phr}$ 以上では分散 相サイズは一定の值を示した. ここで, Fig. 1の分散相の形状 およびFig. 3のSEBS添加量と分散相サイズの関係より, SEBS の添加量増加に伴う PP/PS系のモルホロジーの変化を考察す る. PP/PS/SEBS系において, SEBSがPSドメインに付着しPS ドメインの界面張力を減少させる（6.3 mN/mから $2.2 \mathrm{mN} / \mathrm{m} ）$ ことが既に報告されている. ${ }^{12)}$ 本研究においても SEBS の添加 による一次分散体サイズの低下は, PSドメインの表面にSEBS が付着することでPP/PS界面の自由エネルギーを減少させた ためと考えられる. また, 過剩量のSEBSの添加では, PS ド メイン表面においてSEBSが飽和し, SEBSの添加量によらず PSドメインの表面状態が変化しなくなるため, 一次分散体の 粒径は変化しなくなるであろう. SEBSが過剩に存在する系で は, この一次分散体がSEBS同士の癒着により凝集し二次分散 体を形成するが，その構成単位である一次分散体の大きさは SEBSの添加量に依存しない. さらに一次分散体表面は主とし てSEBSによって構成されていると考えられ,一次分散体間の 凝集力もSEBSの添加量に大きくは依存しないであろう. 結果 として, SEBSの添加量の増加に伴う二次分散体の大きさは SEBS の添加によって変化せず, 分散相サイズに変化が観察さ れなかったと考えられる.

ブレンド物の動的粘弾性特性を評価する前に各ポリマー 単体の特性を示す. Fig. 4にPP, PS, SEBS単体の動的粘弾性 スペクトルを示す. 各ポリマーの貯蔵弾性率 $\left(E^{\prime}\right)$ を比較する とすべての測定温度範囲において SEBSが最も低い值を示し, 最も変形し易い材料であることが分かった. 一方, SEBS, PP, PSの各損失弾性率 $\left(E^{\prime \prime}\right)$ は $235 \mathrm{~K}, 273 \mathrm{~K}, 373 \mathrm{~K}$ にそれぞれピーク を示した. このピークは各ポリマーのガラス転移に由来する ものであり, ピーク温度は各ポリマーのガラス転移温度を示 している.このことから, 室温において, PSはガラス状態, PPは皮革状態，SEBSはゴム状態であることがわかる。

Fig. 5にPP/PS系におけるPSガラス転移温度付近の動的粘弾 性スペクトルを示す.ここでは, 日常の使用時の条件と考え られる, PPが皮革状態となる領域を扱い, 特にPSのガラス転 移温度付近に着目する. 左側の図がSEBSを添加していない

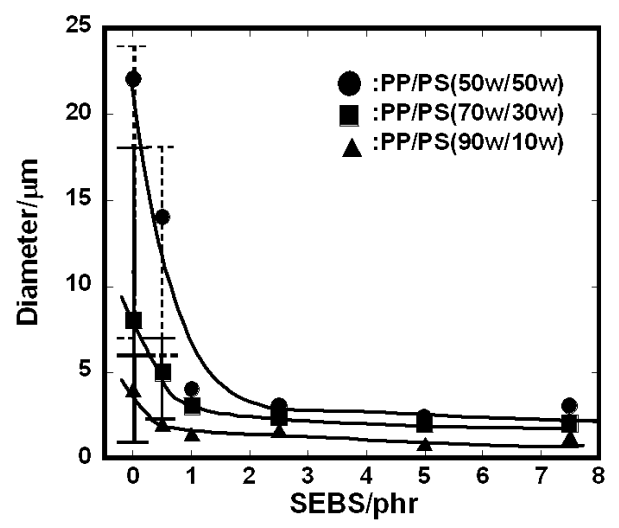

Fig. 3. Plot of diameter of PS domains with different content of SEBS addition for PP/PS.
系, 右側の図がSEBSを 5 phr添加した系の動的粘弾性曲線で ある.すべてのブレンド系のE'はPSのガラス転移温度以上で 急激に低下した。これはPSが緩和するためであると考えられ る.また, PSのガラス転移温度以下の領域ではPS含有量が増 加するに伴い $E^{\prime}$ は高い值を示すのに対し, PSのガラス転移温 度以上の領域ではPS含有量が増加するに伴い低い值を示し た.PSのガラス転移温度近傍では，ガラス状態のPSドメイン

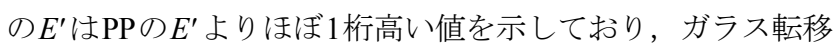
温度以下の領域ではPSはPPに対する有効な補強剤として機 能していることがわかる. 一方, PSのガラス転移温度以上の 温度域ではPSの $E^{\prime}$ はPPに対して無視できるほど小さく, PS 含有量の増加に伴い $E^{\prime}$ が減少したと考えられる. また, PSに PPを添加することでPSのガラス転移温度が高温側へシフト することが報告されているが21), 本研究においてもPPの添加 量の増加に伴いPSのガラス転移温度を示す $E^{\prime \prime}$ の $373 \mathrm{~K}$ 付近の ピークはPPの含有量の増加に伴い高温側へ徐々にシフトし た. さらに, SEBSを5 phr添加したPP/PS系についても, PP/PS 系と同様に $E^{\prime \prime}$ のピークはPS添加量の増加に従い高温側にシ フトした. これらのことから, SEBSの有無に関係なく, PP

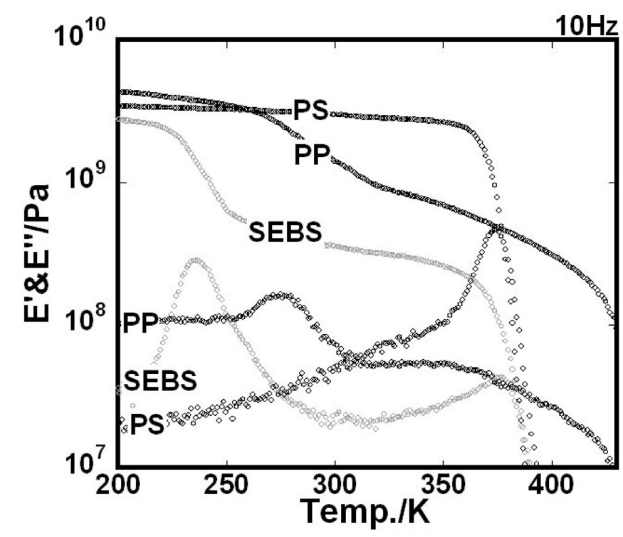

Fig. 4. Dynamic mechanical spectra of PP, PS and SEBS.

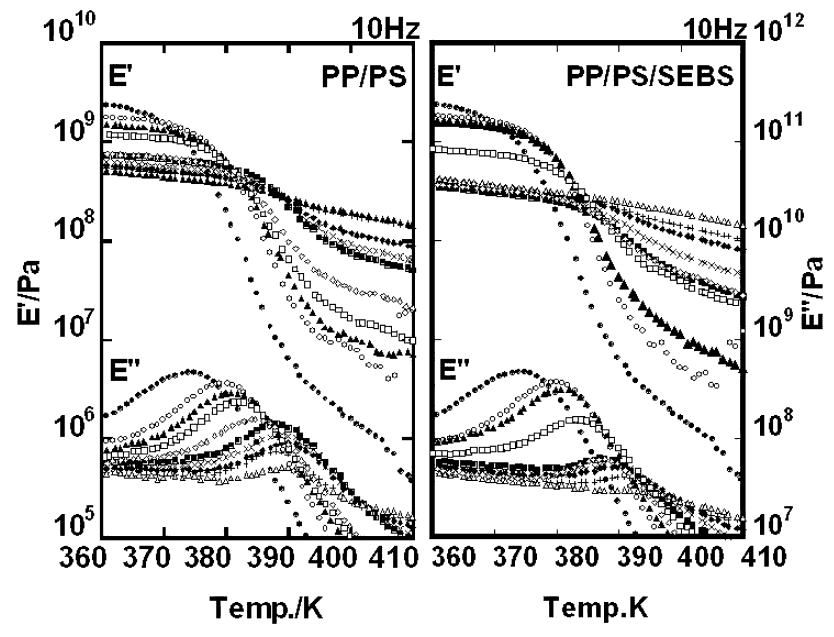

Fig. 5. Dynamic mechanical spectra around $T_{\mathrm{g}}$ of PS in PP/PS and PP/ PS/SEBS blends.

๑:PP: $0 \mathrm{wt} \%$, O:PP $10 \mathrm{wt} \%, \boldsymbol{\Delta}:$ PP $20 \mathrm{wt} \%, \square: P P 30 \mathrm{wt} \%$, $\diamond:$ PP $40 \mathrm{wt} \%, \mathbf{\square}:$ PP $50 \mathrm{wt} \%, \times:$ PP $60 \mathrm{wt} \% \diamond:$ PP $70 \mathrm{wt} \%,+:$ PP $80 \mathrm{wt} \%, \triangle: \mathrm{PP} 90 \mathrm{wt} \%$ 
含有量の増加に伴いPSのガラス転移温度は高温側へ徐々に シフトすることが分かった.

Fig. 5より得られるPSのガラス転移温度を, PP/PS系のPP含 有量に対してプロットした結果を Fig. 6 に示す. PP含有量が 0 60 wt\% の領域ではPP含有量の増加に伴いPSのガラス転移 温度は徐々に上昇するのに対し，60 90 wt\% の領域ではPSの ガラス転移温度の上昇はレベルオフして一定の值を示した. また, PP添加によるPP/PS系中でのPSガラス転移温度の上昇 はSEBSの有無に関係無く，最大 $15 \mathrm{~K}$ 程度であった.

このガラス転移温度の高温側へのシフトを理解するため にPS単体, PP/PS $(50 \mathrm{w} / 50 \mathrm{w})$ 系およびSEBSを $5 \mathrm{phr}$ 添加したPP/ $\mathrm{PS} / \mathrm{SEBS}(50 \mathrm{w} / 50 \mathrm{w} / 5 \mathrm{w})$ 系のPS のガラス転移温度の周波数依 存性をアレニウス式に基づき解析した.アレニウス式は式(1) のように書ける.

$$
\ln f=-\frac{\Delta H}{R T}+\frac{\Delta S}{R}+\ln A
$$

ここで, $f$ は測定周波数, $\Delta H$ は活性化エンタルピー, $R$ は気 体定数, $T$ は絶対温度, $\Delta S$ は活性化エントロピー, A は頻度因 子である. Fig. 7にPS 単体および各ブレンド系のアレニウス プロットを示す．すべての系において傾きは同程度であるこ とから, PP との混練やSEBSの添加によって活性化エンタル ピーは変化せず，PSのガラス転移の活性化機構は同一である ことが示唆される. 一方, PP との混練によりアレニウスプ ロットの切片の值は $1 / 170$ に大きく減少したが, SEBSの添加 によっては大きく変化しなかった。この切片の減少は, 活性 化機構の頻度因子か活性化エンタルピーに起因する. 頻度因 子はガラス転移において緩和しうる鎖数と密接に結びつい ており, 緩和強度からその減少の程度を見積もることが出来 る. 詳細は後述するが, Fig. 8 に示される緩和強度のPS含有 量依存性より, 該当する PP/PS $(50 \mathrm{w} / 50 \mathrm{w})$ の緩和強度のPS 単体 に対する低下は $1 / 100$ 程度で有り, 切片の減少量よりかなり小 さい. このことは, アレニウスプロットの切片の減少には, 頻 度因子の寄与のみではなく, $\Delta S$ の減少も大きく寄与している ことを示唆する. この $\Delta S$ の減少は, PP/PS系ブレンドでは, PP 相の大きな熱収縮によってPS相の熱収縮が抑えられることを 意味しており, 溶融前後でのPS相の体積変化 (エントロピー) は，PSのみを冷却した場合よりも小さくなる．PSマトリック ス中にPPドメインが均一に分散した系では, PPドメインの大
きな熱収縮により, PP ドメイン周囲のPS相の熱収縮は抑制さ れるであろう。この抑制効果はPP との界面積が広くなるほど 顕著に現れ，PS相がドメインを形成するPPマトリックス系へ と転じると，すべてのPS相がPP相と界面を形成し開放端を有 するPS相が存在しなくなるため, その抑制効果は飽和する. また, SEBS添加系では, 主として界面に存在するゴム状態の SEBSがPP相とPS相の癒着性を高めることから, PPやPSより $E^{\prime}$ が小さく変形しやすいSEBSが，PP とPSの熱収縮率の差に よるPS相の変形を小さくする効果があるように思われる。し かし，ゴム状態であるSEBSは，PP相と同様にPS相よりも大 きな熱収縮率であると考えられ，熱収縮率の抑制の点から見 れば，PP相と同様の働きをするであろう.

つぎに, PS含有量が10-90 wt \%のPP/PS系およびSEBSを $5 \mathrm{phr}$ 添加したPP/PS/SEBS 系のPSのガラス転移温度前後での緩和 強度についての調査結果を示す.PSのガラス転移の緩和強度 $R$ は式(2)で与えられる.

$$
R=\frac{E_{370}-E_{400}}{E_{400}}
$$

ここで， $E_{370}$ はPSがガラス状態である $370 \mathrm{~K} の E^{\prime} ， E_{400}$ はPSが ゴム状態である $400 \mathrm{~K} の E^{\prime}$ をれぞれ示している. Fig. 8 にPS 含有量に対して各サンプルのガラス転移の緩和強度をプ ロットした結果を示す.PS含有量の増加に伴いPP/PS系のPS のガラス転移に由来する緩和強度は増大した。この緩和強度 の増大はブレンド物中のPS 含有量の増加に伴いPSのガラス 転移に由来する緩和要素が増加したことが原因と考えられ る.また, 緩和強度はすべての混合比において SEBSを添加す ることで低下し，PS含有量が $60 \mathrm{wt} \%$ 付近で最も大きく緩和強 度に及ぼすSEBSの有無の差が表れることが分かった.

PP/PS系の動的粘弾性特性に及ぼすSEBSの添加効果を評価 する前に, PPおよびPS単体の動的粘弾性特性に及ぼすSEBS の添加効果について調べる必要がある。ここでも，PPが皮革 状態の領域を対象とし, 特にPSのガラス転移温度付近に着目 する. Fig. 9にPPおよびPSにSEBSを0-7.5 phr添加したPSのガ ラス転移温度付近の動的粘弾性スペクトルを示す.PPにSEBS を添加すると弾性率の低いSEBS と複合効果により $E^{\prime}$ が低下 したが, $E^{\prime \prime}$ はSEBSの添加量に関係なく一定の值を示した.一 方, PSにSEBSを添加してもE'およびE"のいずれもほとんど

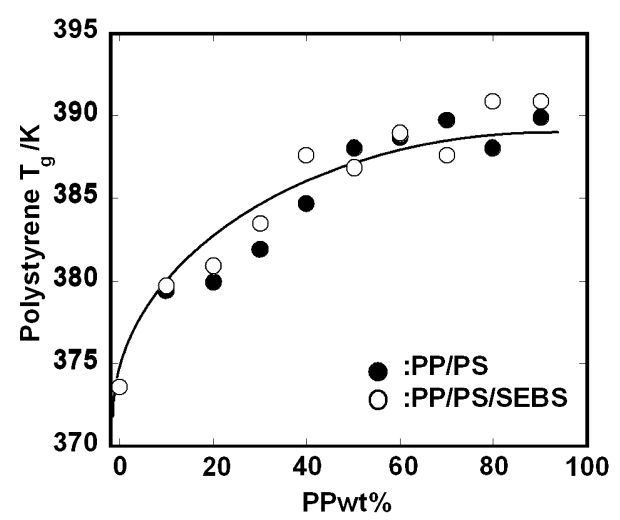

Fig. 6. $T_{\mathrm{g}}$ of PS plotted against PS content in PP/PS.

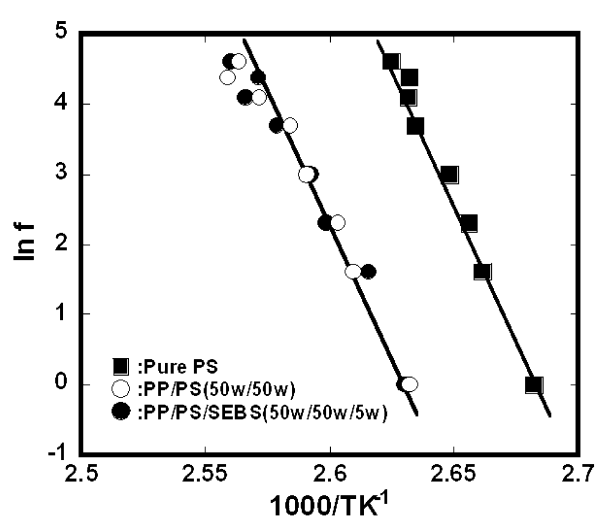

Fig. 7. Arrhenius plots of Pure PS and PP/PS blends. 
変化せず, SEBSの添加効果は認められなかった.

Fig. 10にPP/PS系の動粘弾性特性に及ぼすSEBSの添加効果に ついて示す. PPがマトリックスとなる $50 \mathrm{w} / 50 \mathrm{w}$ 系, $70 \mathrm{w} / 30 \mathrm{w}$ 系および $90 \mathrm{w} / 10 \mathrm{w}$ 系にSEBSを0-7.5 phr添加したときのPSガ ラス転移付近の動的粘弾性スペクトルは, いずれのPS含有量 においてもSEBSの添加量の増加に伴い $E^{\prime} か ゙$ 徐々に低下した. SEBSは，PPが皮革状態となる領域において，ゴム状態もしく は流動状態であり, PPよりも1杵以上小さい $E^{\prime}$ を示す(Fig. 4). したがって, この弾性率の低下は, PPマトリックスに弾性率 の低いSEBSが添加されたことが主たる要因であろう。しか し, $390 \mathrm{~K}$ 付近に見られるPSのブレンド試料の $E^{\prime}$ の低下は, $T_{\mathrm{g}}$ 以下の温度よりも大きく, PSの $T_{\mathrm{g}}$ 以下の温度において単純な 弾性率の低い物質との複合効果以外の $E^{\prime}$ を低下させる要因が あることを暗示している. SEM観察でも述べたように, PP/ PS/SEBS 系の分散相は最も弾性率の低いSEBSがPSドメイン を覆い囲みSEBSの層を形成している.このような分散相を有 寸る系に外力を加えた場合, 最も変形し易いSEBS 層に応力が

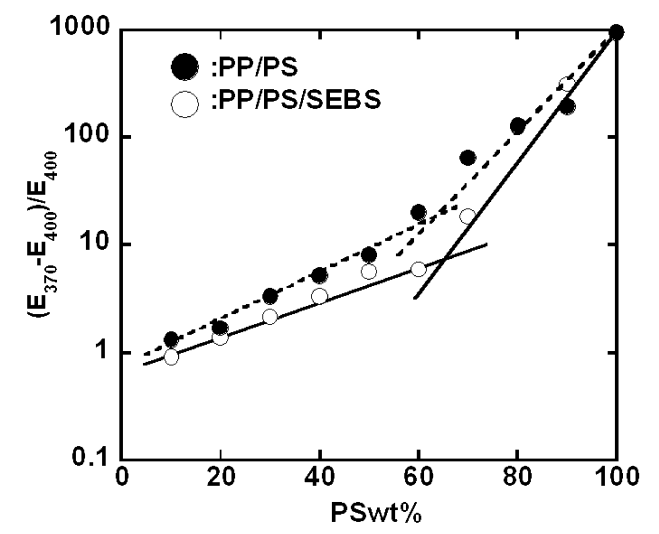

Fig. 8. Relaxation strengths plotted against PS content in PP/PS and PP/ PS/SEBS.
集中し $E^{\prime}$ が低下したと考えられる.PP/SEBS系, PS/SEBS系 において $E^{\prime}$ に顕著な添加効果が表れないのはこのような SEBS層が形成されないためと思われる.

また，PS単体にSEBSを添加してもほとんどPSのガラス転

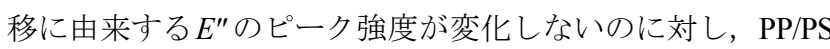
系の $E^{\prime \prime}$ のピーク強度はSEBSの添加量の増加に伴い顕著に低 下することが分かった(Fig. 10). これは, SEBSを添加するこ とでPP/PS系中のPSのガラス転移に由来する $373 \mathrm{~K}$ 前後の緩和 強度が低下したことを意味している. Fig. 11 にFig. 10 の各サ ンプルの緩和強度を式(2)より算出し, SEBSの添加量に対し てプロットした結果を示す。いずれのPS含有量においても SEBS 添加量が $2.5 \mathrm{phr}$ までは緩和強度は低下傾向を示すもの の2.5 phr以上添加しても緩和強度は一定の值を示した。

この緩和強度のSEBS 添加量依存性は分散相サイズのSEBS 添加量依存性に酷似しており (Fig. 3)，このことは，PSのガラ ス転移に由来する緩和強度の低下が一次分散体の表面状態 と関連していることを暗示する。 すなわち, PSドメインの表

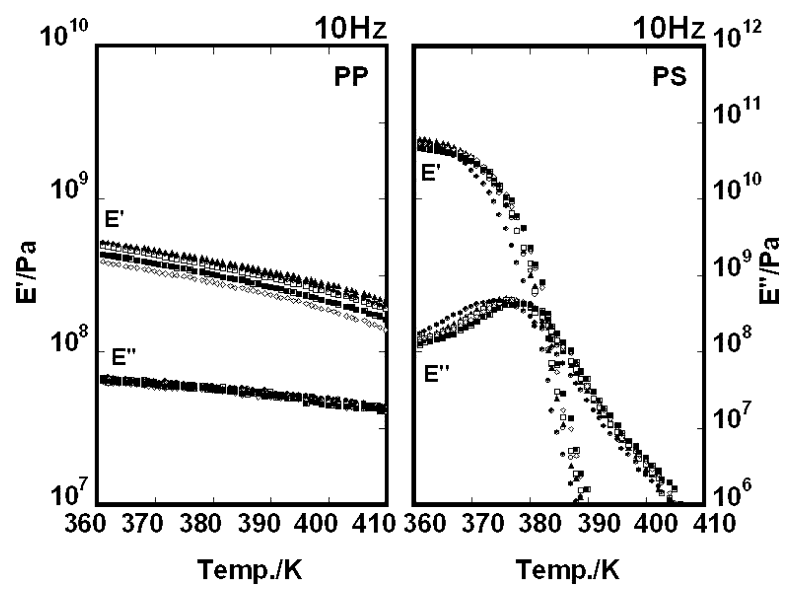

Fig. 9. Dynamic mechanical spectra of PP and PS with SEBS around $T_{\mathrm{g}}$ of PS. ○:SEBS 0 phr, O:SEBS $0.5 \mathrm{phr}, \boldsymbol{\Delta}$ :SEBS $1.0 \mathrm{phr}, \square$ :SEBS $2.5 \mathrm{phr}$ $\diamond$ :SEBS $5.0 \mathrm{phr}$, $\mathbf{\square}$ :SEBS $7.5 \mathrm{phr}$.

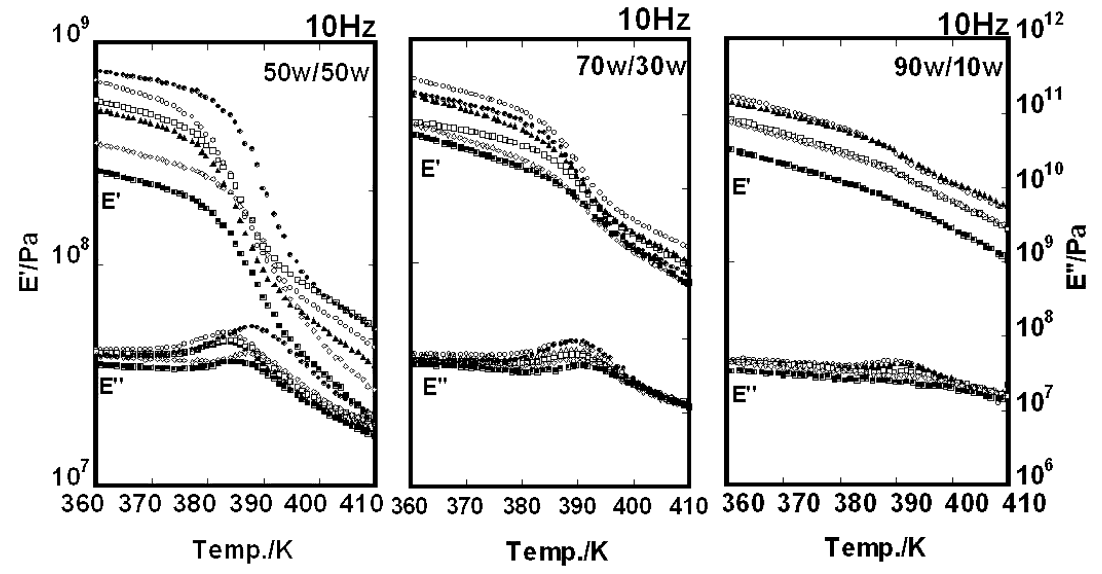

Fig. 10. Dynamic mechanical spectra of PP and PS with SEBS around $T_{\mathrm{g}}$ of PS.

$\bullet$ :SEBS 0 phr, $\bigcirc$ :SEBS $0.5 \mathrm{phr}, \boldsymbol{\Delta}$ :SEBS $1.0 \mathrm{phr}, \square$ :SEBS $2.5 \mathrm{phr}, \diamond$ :SEBS $5.0 \mathrm{phr}$,

口:SEBS $7.5 \mathrm{phr}$.

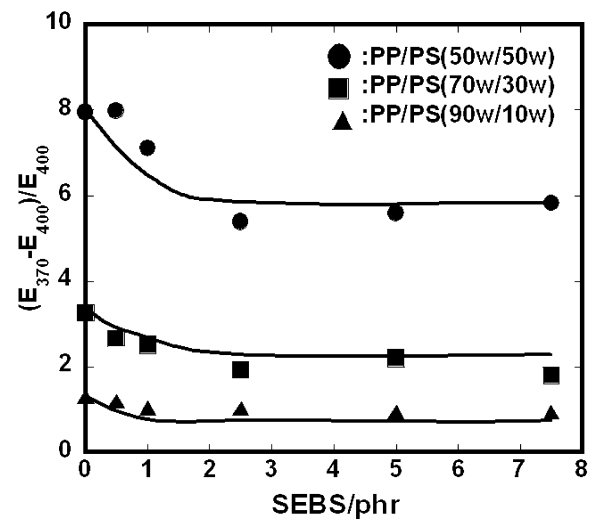

Fig. 11. Relaxation strengths plotted against SEBS content in PP/PS/SEBS. 
面近傍のPSは，SEBSの緩和に誘発され実際の緩和温度より も低温側で緩和してしまい，ドメイン内部の純粋なPSが示す 緩和温度で緩和要素が減少したと解釈することができる。ま た，この解釈に従えば，PPとPSの相反転付近で，SEBS添加 時にSEBS と接するPS表面積が最大となる $40 \mathrm{w} / 60 \mathrm{w}$ 系 ${ }^{23)}$ で, 最 も大きくPSのガラス転移に由来する緩和強度への SEBS の添 加効果が表れたことも説明することができる(Fig. 8).

\section{4. 結言}

本研究ではPP/PS系へのSEBS添加がモルホロジーと動的粘 弾性特性に与える影響についての調査を行った。

PP-rich PP/PS系ブレンドにおいてSEBSを添加することで劇 的にPSドメインサイズが低下した。しかしながら，2.5 phr以 上SEBSを添加してもPSドメインが二次凝集体を形成してし まうために分散相のサイズは低下しないことが分かった. PP/ PS 系のPSのガラス転移温度はPP含有量の増加に伴い高温側 へ徐々にシフトすることが知られているが，この現象はPSの 活性化エントロピーがPP含有量の増加に伴い減少したこと が原因である. PS含有量の減少に伴いPSのガラス転移温度付 近の緩和強度は低下し，さらにSEBSをPP/PS系に添加するこ とで $E^{\prime}$ とPSのガラス転移の緩和強度が低下した。一方，PPお よびPS 単体にSEBSを添加してもほとんど添加効果が表れな かった。これらのことから PP/PS系ブレンドへSEBSを添加す ることでSEBSがPSドメインを覆い囲む一次分散体を形成し， このSEBS層の存在がPP/PS系の動的粘弾性特性に影響を及ぼ すことが示唆される結果が得られた。

\section{REFERENCES}

1) Yordanov C, Minkova L, European Polymer Journal 41, 527 (2005).

2) Minkovaa L, Yordanova H, Filippib S, Grizzutic N, Polymer 44, 7925 (2003)

3) Wilkinson AN, Laugel L, Clemens ML, Harding VM, Marin M, Polymer, 40, 4971 (1999).
4) Wilkinson AN, Clemens ML, Harding VM, Polymer, 45, 5239 (2004).

5) Ohisson B, Hassander H, Tornell B, Polymer, 39, 6705 (1998).

6) Kim G-M, Michler GH, Polymer, 39, 5689 (1998).

7) Kim G-M, Michler GH, Polymer, 39, 5699 (1998).

8) Chen B, Huang B, Polymer, 43, 953 (2002).

9) Eklind H, Maurer FHJ, Polymer, 37, 4465 (1996).

10) Taoa Y, Lebovitza AH, Torkelson JM, Polymer, 46, 4753 (2005)

11) Horiuchi S, Matchariyakult N, Yase K, Kitano T, Polymer, 37, 3065 (1996).

12) Macaubas PHP, Demarquette NR, Polymer, 42, 2543 (2001).

13) Halimatudahliana, Ismail H, Nasir M, Polymer Testing, 21, 263 (2002)

14) Halimatudahliana, Ismail H, Nasir M, Polymer Testing, 21, 163 (2002).

15) Lee S-G, Lee JH, Choi K-Y, Rhee JM, Polymer Bulletin, 40, 765 (1998).

16) Albanoab C, Reyesb J, Ichazoc M, Gonzalezc J, Hernandezc M, Rodrguezb M, Polymer Degradation and Stability, 80, 251 (2003)

17) Zhang Q, Yang H, Fu Q, Polymer, 45, 1913 (2004)

18) Rek V, Grguric TH, Jelcic Z, Hace D, e-Polymer, 34 (2004).

19) Wang Y, Xiao Y, Zhang Q, Gao X-L, Fu Q, Polymer, 44, 1469 (2003)

20) Yoshida K, Kawamura T, Terano M, Nitta K-H, J. Applied Polymer Science., in press.

21) Mucha M, Colloid and Polymer Science, 264, 859 (1986).

22) Hobbs SY, Dekkers MEJ, Watkins VH, Polymer, 29, 1598 (1988).

23) Wang Y, Xiao Y, Zhang Q, Gao X-L, Fu Q, Polymer, 44, 1469 (2003). 